\title{
Feeding ecology of Ara ararauna (Aves, Psittacidae) at firebreaks in western Cerrado, Brazil
}

\author{
Dárius Pukenis Tubelis \\ Departamento de Ecologia, Instituto de Biociências, Universidade de São Paulo \\ Rua do Matão, 321, Travessa 14, CEP 05508-900, São Paulo - SP, Brazil \\ dtubelis@yahoo.com
}

Submetido em $11 / 08 / 2008$

Aceito para publicação em 02/03/2009

\begin{abstract}
This study aimed to identify food items of the Blue-and-yellow Macaw (Ara ararauna) flocks foraging at firebreaks in western Cerrado, Brazil. Also, I discuss ecological aspects of macaw feeding activities at firebreaks. Two 3,500ha portions of Emas National Park were selected for observations. The sites were mosaics of woodland savanna and shrubby grassland, crossed and bordered by firebreaks and adjacent unsealed roads. A total of 76 foraging flocks of macaws were recorded at firebreaks between September 2006 and February 2007. Seven plant species were identified as food items. Seeds of a shrub species (Anacardium humile) were the most often consumed resource. Parts of other plant species were sometimes consumed. Macaws perched in tree canopies to consume their young apical parts, young leaves, flowers and parts of branches. The frequency of consumption of parts of shrubs was significantly higher than that of trees. At Emas National Park, numerous Blue-and-yellow Macaw flocks are attracted to firebreaks mainly by fruiting A. humile patches. Their foraging activities often damage reproductive and young parts of shrubs and trees.
\end{abstract}

Key words: Anacardium humile, bird, diet, fire ecology, savanna

\section{Resumo}

Ecologia alimentar de Ara ararauna (Aves, Psittacidae) em aceiros no oeste do Cerrado, Brasil. Este estudo teve como objetivo identificar itens alimentares de bandos de araras-canindé (Ara ararauna) forrageando em aceiros na região oeste do Cerrado, Brasil. Eu discuto aspectos ecológicos de atividades alimentares de araras em aceiros. Duas porções (cerca de 3.500ha cada) do Parque Nacional das Emas foram selecionadas para o estudo. Os locais de estudo eram mosaicos de campo cerrado e campo sujo cruzados e envoltos por aceiros e estradas de terra adjacentes. Um total de 76 bandos foi registrado forrageando em aceiros entre setembro de 2006 e fevereiro de 2007. Sete espécies de plantas foram identificadas como itens alimentares. Sementes de cajuzinhos-do-cerrado (Anacardium humile) foram o recurso mais frequentemente consumido. Partes de outras espécies de plantas foram eventualmente consumidas. Araras pousaram em copas de árvores para consumir suas partes apicais, folhas jovens, flores e parte de galhos. A frequência de consumo de partes de arbustos foi significantemente mais alta do que aquela de árvores. No Parque Nacional das Emas, numerosos bandos de arara-canindé são atraídos a aceiros principalmente por manchas de cajuzinhos em frutificação. Suas atividades alimentares geralmente causam danos a partes reprodutivas e apicais de arbustos e árvores.

Unitermos: Anacardium humile, aves, dieta, ecologia do fogo, savana 


\section{Introduction}

The Blue-and-yellow Macaw (Ara ararauna) occurs in southern Central America and widely in tropical South American countries (Forshaw, 1989; Stotz et al., 1996). In Brazil, it is widely distributed mainly through Amazonia, the Cerrado and the Pantanal (Sick, 1997; Sigrist, 2006). It is found in a diverse range of forest types, woodland savannas and open vegetation marked by high numbers of palm trees (Forshaw, 1989; Juniper and Parr, 1998; Sigrist, 2006). Habitat loss and exploitation for the pet trade have contributed to its disappearance in some regions (del Hoyo et al., 1997; Juniper and Parr, 1998).

Detailed studies on wild Blue-and-yellow Macaws have examined aspects such as activity patterns (Roth, 1984), breeding biology (Bianchi, 1998; Brightsmith and Bravo, 2006) and habitat use (Gilardi and Munn, 1998; Renton, 2002; RagusaNetto, 2006). However, its feeding habits have rarely been examined in detail.

Most information on the diet of the Blue-andyellow Macaw is available as brief comments in major publications on South American birds or in general overviews of several psittacid species (Forshaw, 1989; del Hoyo et al., 1997; Juniper and Parr, 1998). Seed consumption has been observed in countries such as Surinam, Peru and Brazil (Haverschmidt, 1954; Trivedi et al., 2004; Haugaasen and Peres, 2005). Equally frequent are reports of fruit consumption, especially palm fruits (Roth, 1984; Sick, 1997; Oehler et al., 2001). Also, there are brief comments on A. ararauna eating fruits of other plants (Roth, 1984; Sick, 1997; Sigrist, 2006). Less frequent plant food items include nectar, arils, flowers and leaves (del Hoyo et al., 1997; Juniper and Parr, 1998; Sigrist, 2006).

In the Cerrado, the savanna ecosystem that dominates central Brazil (Oliveira and Marquis, 2002; Scariot et al., 2005), information on the diet of the Blue-and-yellow Macaw is lacking. Brief observations on their feeding habits have been made in woodland savannas (Sick, 1997; Faria et al., 2007), while detailed studies have been conducted in veredas and cerradão (Villalobos, 1994; Ragusa-Netto, 2006).

Most records of their feeding groups in the Central and South Americas have occurred in forests and vegetation with abundant palm trees. Also, no studies have quantified the use of different plant species by the Blue-and-yellow Macaw in open cerrado vegetation. Today, such habitats include firebreaks - bands of woodlands and grasslands managed for fire control in protected areas. At Emas National Park, for example, firebreaks are a common landscape feature (França et al., 2007), and they are often used as foraging sites by this macaw species (personal observation).

This study aimed to identify major food items of the Blue-and-yellow Macaw at firebreaks maintained in woodland savannas (campo cerrado) and shrubby grasslands (campo sujo) at Emas National Park, Goias state, Brazil. The frequency of consumption of shrub and tree species by the macaws was documented and I discuss my results in relation to available food items in the Cerrado and other regions. I also discuss firebreaks as feeding sites and interactions between macaws and other wildlife at firebreaks.

\section{Material and Methods}

\section{Study area}

This study was conducted at Emas National Park, a 132,000ha nature reserve located in southwestern Goias state $\left(17^{\circ} 49^{\prime}-18^{\circ} 28^{\prime} \mathrm{S}\right.$ and $\left.52^{\circ} 39^{\prime}-53^{\circ} 10^{\prime} \mathrm{W}\right)$, Brazil. It harbors most of the typical physiognomies of the Cerrado's landscapes. Grasslands are the dominant vegetation cover (França et al., 2007). Campo limpo is grassland with few shrubs and no trees, while campo sujo is grassland with numerous shrubs and scattered trees (Eiten, 1972; Oliveira Filho and Ratter, 2002). Woodlands are less dominant but cover substantial portions of uplands. Woodland savanna vegetation with intermediate and higher densities of shrubs and trees is called campo cerrado and cerrado sensu stricto, respectively (Oliveira Filho and Ratter, 2002). The 
cover of grasses is lower in woodland savannas than in grasslands (Castro and Kauffman, 1998). Other physiognomies within the park are riparian forests, wet fields and veredas (Ramos Neto and Pivello, 2000; França et al., 2007). Further information on the Cerrado's physiognomies can be found in Eiten (1972), Coutinho (1978) and Ribeiro and Walter (1998).

Elevation ranges between 720 and $900 \mathrm{~m}$ above sea level, and most of the park consists of flat tableland covered by grasslands (Ramos Neto and Pivello, 2000). The regional climate is marked by two well-defined periods - wet and dry seasons (Assad, 1994). Most of the annual precipitation falls between October and March. Annual rainfall ranges between 1,200 and 2,000mm. The dry season occurs between May and September. Temperatures occasionally reach $0^{\circ} \mathrm{C}$ in the winter (July) and $40^{\circ} \mathrm{C}$ in the summer (January, February) (Assad, 1994).

Within Emas National Park, fires can be natural or human-induced (França et al., 2007). Natural fires usually occur in the wet season and reach relatively small areas. On the other hand, human-induced fires often occur during the dry season and can spread through extensive portions of the park (Ramos Neto and Pivello, 2000). Fire management is basically restricted to maintenance of firebreaks (aceiros) - bands of grassland or woodland vegetation that are burned in the early dry season (usually June), every 1-2 years. Firebreaks are located between two dirt roads and are burned in an attempt to stop fire spreading during the dry season (Ramos Neto and Pivello, 2000; França et al., 2007).

\section{Study sites}

Two 3,500ha portions of Emas National Park were sampled. They were $35 \mathrm{~km}$ from each other and were located in the southeastern and northwestern portions of the park. These study sites were mosaics of campo cerrado and campo sujo vegetation crossed and bordered by unpaved roads of about $7 \mathrm{~m}$ in width. Adjacent to these roads were firebreaks ranging from 20 to $80 \mathrm{~m}$ in width. Aceiros maintained in campo cerrado and in campo sujo vegetation are here called "woodland firebreaks" and "grassland firebreaks", respectively. The study sites were dominated by capim flecha grass (Tristachya leiostachya Ness). This grass is $100-220 \mathrm{~cm}$ high in woodland savannas and shrubby grasslands. In the firebreaks, the grass is much shorter (10-25 cm high), as park managers burned most firebreaks of the study sites in June 2005. At a few firebreaks (not burned in 2005 and 2006), the height of T. leiostachya grass was about $70 \mathrm{~cm}$. The study sites were more than $2 \mathrm{~km}$ from veredas - major roosting, nesting and feeding sites of $A$. ararauna (Sick, 1997; Bianchi, 1998; Sigrist, 2006).

\section{Bird observations}

Field work was divided into six sampling periods between September 2006 and February 2007 (Table 1). Sampling consisted of driving a vehicle along roads, searching for macaw flocks foraging in firebreaks during the morning (09:00 - 10:30h) and afternoon (15:30 17:30h) on a given day. Macaws could be easily detected from the vehicle due to high conspicuousness and because firebreaks were adjacent to roads. Observations from the vehicle on feeding habits started immediately after a flock was detected. I also approached macaws on foot to better observe their feeding habits. Usually, macaws flew away after alarm calls made by sentinel members of the group. Observations on each foraging flock lasted from a few seconds to a few minutes.

During observations, food items consumed by flock members were recorded. For each flock, the consumption of a given plant species was recorded only once, even if several flock members were feeding on this resource (e.g., Anacardium seeds). After a flock left a feeding site, it was not followed. Further sampling was done by driving in search of other flocks. Plants consumed by macaws were photographed for identification purposes. 
TABLE 1: Sampling periods, the number of days of observations in each period, and the number of Blue-and-yellow Macaw flocks feeding on different plant species in woodland (W) and grassland (G) firebreaks, and in both types of firebreaks $(\mathrm{T})$, between September 2006 and February 2007 at Emas National Park, western Brazilian Cerrado.

\begin{tabular}{lccccccc}
\hline & & \multicolumn{2}{c}{$\begin{array}{c}\text { Number of } \\
\text { flocks }\end{array}$} & \multicolumn{4}{c}{$\begin{array}{c}\text { Number of } \\
\text { plant species } \\
\text { exploited }\end{array}$} \\
\cline { 2 - 8 } & & W & G & T & W & G & T \\
\hline 12-20 September & 9 & 33 & 8 & 41 & 7 & 2 & 7 \\
1-12 October & 12 & 28 & 7 & 35 & 7 & 1 & 7 \\
10-18 November & 5 & 0 & 0 & 0 & 0 & 0 & 0 \\
14-22 December & 6 & 0 & 0 & 0 & 0 & 0 & 0 \\
13-28 January & 10 & 0 & 0 & 0 & 0 & 0 & 0 \\
3-28 February & 12 & 0 & 0 & 0 & 0 & 0 & 0 \\
Total & 54 & 61 & 15 & 76 & 7 & 2 & 7 \\
\hline
\end{tabular}

\section{Analyses}

The frequency of consumption of a plant species was considered as the number of flocks that fed on this species in relation to the total number of flocks recorded. Plants whose parts were eaten by macaws were divided into two categories: trees (plants $>2.0 \mathrm{~m}$ high) and shrubs (plants $<1.0 \mathrm{~m}$ high). Plants of intermediate height were not consumed by macaws. The chi-square test was used to compare the frequencies of consumption of trees and shrubs using BioEstat 2.0 (Ayres et al., 2000). Significance was set at $\mathrm{p}<0.01$.

\section{Results}

A total of 76 feeding flocks of the Blue-and-yellow Macaw was recorded in the studied firebreaks (Table 1). Flock size ranged from 2 to 34 individuals. Usually, no other bird species foraged with macaws. The only exception was a Toco Toucan (Ramphastos toco) feeding on the ground with a flock of six macaws at a woodland firebreak. No feeding flocks were observed between November and February. Thus, foraging flocks were found at firebreaks only in September and October (Table 1).
In both months, seven plant species had parts eaten by macaws, and Anacardium humile was the most frequent food item. Other species were eaten occasionally (Figure 1). Of the seven plant species consumed, three were shrubs and four were trees. In total, 69 (90.8\%) flocks foraged in shrubs, while 15 (19.7\%) flocks foraged in trees. As a result, the frequency of consumption of parts of shrubs was significantly higher than that of trees $\left(\chi^{2}=34,714 ; \mathrm{df}=1 ; \mathrm{p}<0.001\right)$. Of the 15 flocks that consumed parts of trees, nine had flock members also feeding on shrubs (A. humile seeds). The importance of A. humile among food items consumed at firebreaks was also remarkable because its seeds were eaten by $86.7 \%$ of the 15 flocks that were recorded exploiting more than one plant species, and by $90.2 \%$ of the 61 flocks that were seen foraging on one plant species alone.

Most records of feeding flocks occurred in woodland firebreaks, where macaws fed on seven plant species (Table 1). The relatively few flocks found in grassland firebreaks consumed only two plant (shrub) species - A. humile and Campomanesia adamantinum. In woodland firebreaks, 55 and 15 flocks consumed parts of shrubs and trees, respectively. Thus, the frequency of consumption of shrubs was significantly higher than that of trees in woodland firebreaks $\left(\chi^{2}=22,857 ; \mathrm{df}=1 ; \mathrm{p}<\right.$ $0.001)$. In both types of firebreaks, $A$. humile was the most frequent food item, with frequencies of consumption of $87 \%$ and $100 \%$ in woodland and grassland firebreaks, respectively. Details on the consumption of each plant species are described below.

Anacardium humile (Anacardiaceae) - This shrub species (Figure 2a) is commonly found in firebreaks. Although it could occur as isolated plants (occupying < $0.5 \mathrm{~m}^{2}$ ), it was more often found as patches covering from 1 to $10 \mathrm{~m}^{2}$. By mid-September, most plants had flowers and young pseudofruits; by mid-October, most plants had mature and dehydrated pseudofruits, and flowers were rare. Plants had no fruits, flowers or pseudofruits between November and February. In both woodland and grassland firebreaks, this species was the most frequent food item during September and October. Macaws consumed seeds of immature and mature fruits (Figure $2 b$ ), including those linked to dehydrated pseudofruits in mid-October. Pseudofruits and flowers were not eaten. 


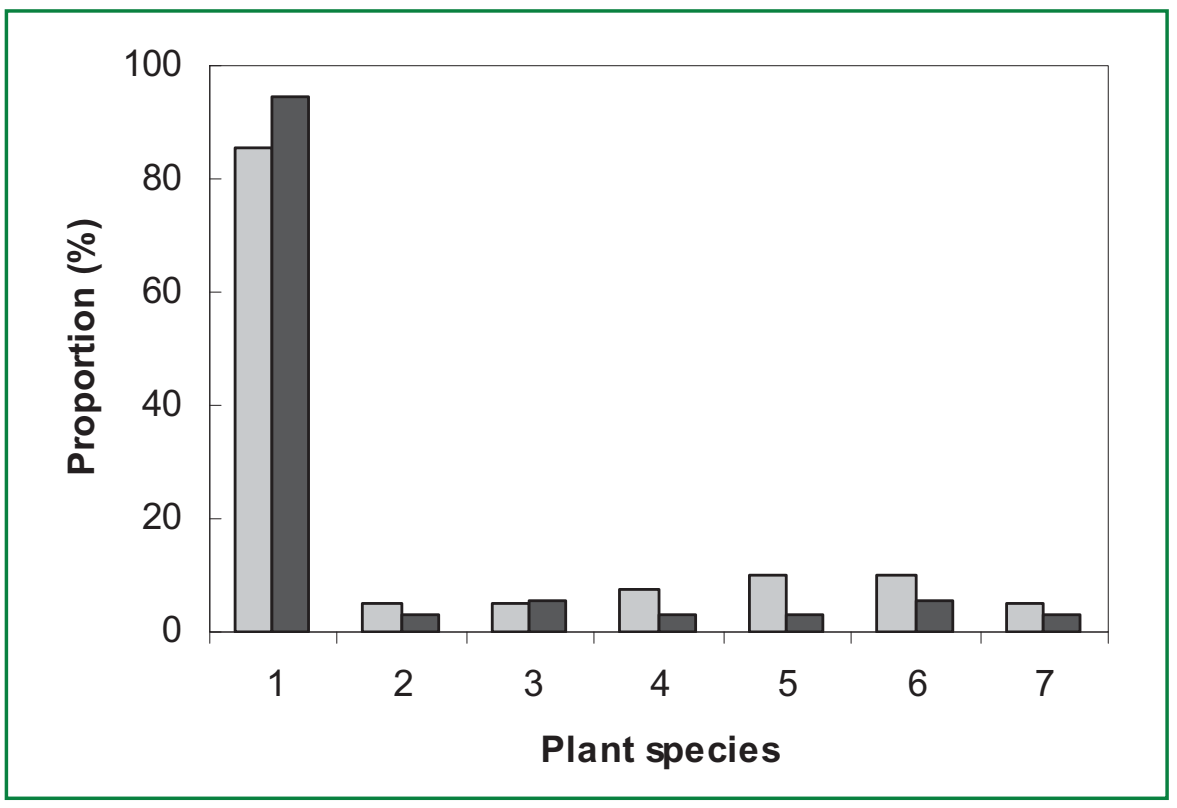

FIGURE 1: Frequency of consumption of different plant species by Blue-and-yellow Macaw flocks in September (gray bars) and October (black bars) 2006, at Emas National Park, Brazil. Plant species are: 1 - Anacardium humile; 2 - Allagoptera leucocalyx; 3 - Campomanesia adamantinum; 4 - Erythroxylum sp; 5 - Pseudobombax sp; 6 - Dimorphandra mollis; 7 - Pouteria rhamiflora.

Macaws landed on the ground (Figure 2c) to gather hanging fruits. They tended to open fruits while on the ground, where broken parts of fruits were usually left (Figure 2d). Dozens of open fruits in the surroundings of large A. humile patches after macaws left the area were frequently found. On three occasions, a macaw was noted cutting off a branch with several fruits. Then, it flew to a nearby tree (Figure 2e), and consumed seeds or dropped the branch with damaged and undamaged fruits (Figure 2f). Similarly, on two occasions, I observed macaws breaking $A$. humile fruits while perched on a termite nest close to other flock members.

Allagoptera leucocalyx (Arecaceae) - This palm, usually shorter than $1 \mathrm{~m}$ (Figure $3 \mathrm{a}$ ), was often found at firebreaks. Plants usually contained one to three fruiting stalks (pinhas). These contained numerous small fruits whose nuts were eaten by macaws. On two occasions (September), macaws were seen flying from woodland firebreaks with a fruit stalk in their bills to perch on a nearby tree. Seconds later, the macaws dropped these stalks, which had both broken and undamaged fruits. In October, a macaw was seen feeding on a fruit stalk while on the ground. On these three occasions, the macaws had broken the peduncle to handle the whole fruit stalk.

Campomanesia adamantinum (Myrtaceae) - These shrubs are usually shorter than $50 \mathrm{~cm}$, and occasionally occur at firebreaks. Plants harbored numerous fruits (Figure 3b). Consumption by macaws was recorded in both types of firebreaks, in September and October. On two occasions, macaws were seen flying with branches harboring these fruits. On two other occasions, I found opened fruits on the ground below where a pair of macaws had been perched. Macaws consumed parts (seeds and probably pulp) of immature (green) and mature (yellow) fruits.

Erythroxylum sp. (Erythroxylaceae) - This tree species is commonly found in woodland firebreaks, where all records of its consumption occurred. In September and October, macaws were noted eating young parts, such as flower buds and sprouting leaves (Figure 3c). Trees often visited by macaws were substantially damaged, showing a 'clean' aspect, with few remaining leaves and growing structures (Figure 3d). 


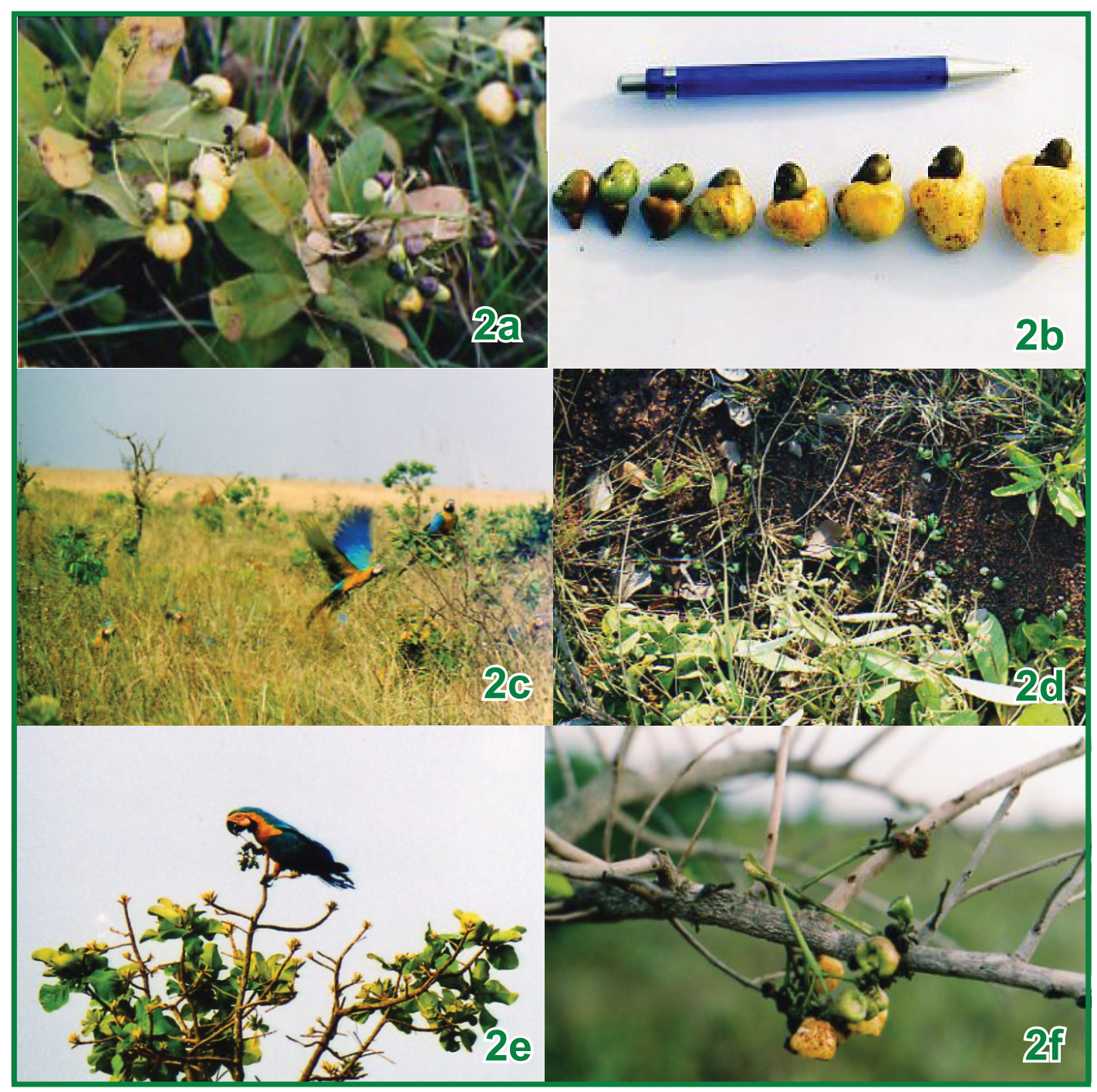

FIGURE 2: Aspects of the consumption of Anacardium humile by the Blue-and-yellow Macaw at firebreaks, between September 2006 and February 2007, at Emas National Park. 2a - part of a plant harboring numerous fruits; $2 b$ - range of maturation of reproductive parts whose seeds were eaten by macaws (fruits linked to dehydrated pseudofruits were not represented); $2 \mathrm{c}-\mathrm{a}$ flock foraging on the ground of a firebreak, with a few sentinel members perched on shrubs; $2 \mathrm{~d}-$ open fruits left on the ground after consumption of seeds; $2 \mathrm{e}-\mathrm{a}$ macaw perched on an unidentified tree holding a branch of $A$. humile, after leaving the ground where it was foraging; $2 \mathrm{f}-\mathrm{a}$ branch of $A$. humile with damaged and undamaged fruits dropped by a macaw.

Pseudobombax sp. (Bombacaceae) - All records of exploitation of this species occurred in woodland firebreaks, mostly in September. Macaws ate the young and apical parts of branches containing the leaves (Figure 3e). A single macaw was seen to destroy up to three of these structures in five minutes. Thus, groups of few macaws caused considerable damage (reduction of the number of young branches with leaves) to these trees in a few minutes.
Dimorphandra mollis (Leguminosae) - This is a common tree in woodland firebreaks. In September and October, its flowers were eaten by macaws (Figure $3 \mathrm{f})$.

Pouteria ramiflora (Sapotaceae)-This is a common tree in woodland firebreaks. The interior and basal parts of young branches were consumed by macaws (no photo available), mainly in September. 

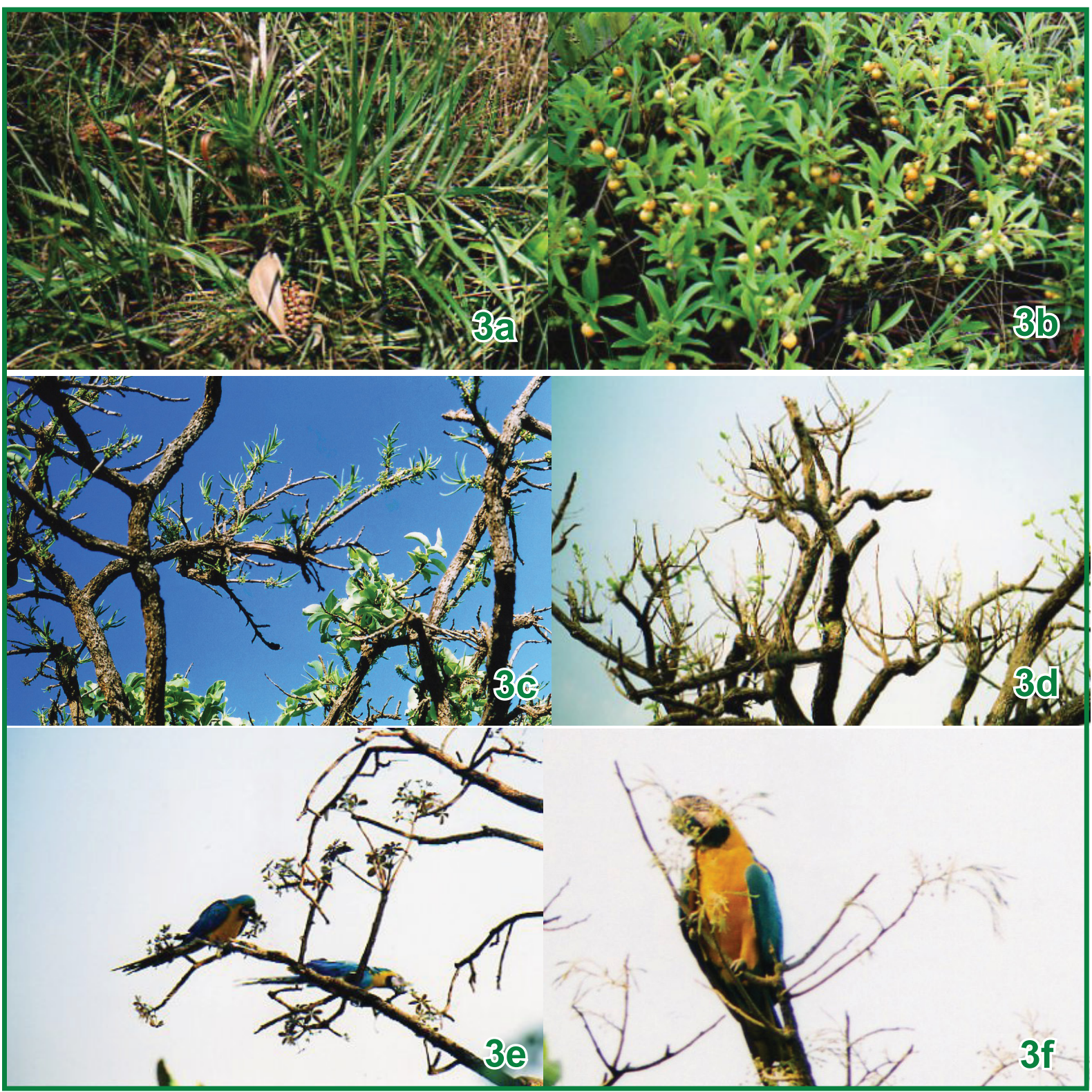

FIGURE 3: Plant species occasionally eaten by the Blue-and-yellow Macaw at firebreaks in September and October 2006, at Emas National Park. 3a - Allagoptera leucocalyx; 3b - Campomanesia adamantinum; 3c - Erythroxylum sp; 3d - substantially damaged Erythroxylum tree; 3e - Pseudobombax sp; 3f - Dimorphandra mollis.

\section{Discussion}

\section{Food items in the Cerrado and other regions}

I observed macaws eating parts of seven plant species at firebreaks. Most of these species had not been noted by previous studies of the Blue-and-yellow Macaw foraging in the Cerrado region. Ragusa-Netto (2006) reported $P$. ramiflora consumption in a cerradão remnant in southwestern Cerrado. Bianchi et al. (2000) had reported the consumption of $A$. humile and $P$. ramiflora fruits by psittacids in the Cerrado, but the parrot species were not identified. Other descriptions of foraging in the Cerrado occurred in veredas (Villalobos, 1994), cerrado sensu stricto (Sick, 1997), cerradão (Ragusa-Netto, 2006; Faria et al., 2007), gallery forests (Ragusa-Netto, 2006) and urban areas (Ragusa-Netto, 2006). These 
studies identified many other food items. My study in grassland and woodland firebreaks adds six species to the known diet of plant species eaten by the Blue-and-yellow Macaw in the Cerrado and in general (Haverschmidt, 1954; Roth, 1984; Forshaw, 1989; del Hoyo et al., 1997; Sick, 1997; Juniper and Parr, 1998; Oehler et al., 2001; Trivedi et al., 2004; Haugaasen and Peres, 2005; Sigrist, 2006). As sampling occurred between September and February, further studies, especially in other periods of the year, might identify other plant species that are consumed by macaws in the region of Emas National Park. Also, other methods of diet analysis, such as the examination of stomach contents, might contribute to the knowledge of their food requirements.

My study was the second to quantify the use of different plant species by feeding flocks of the Blue-andyellow Macaw in the Cerrado. A pioneer study showed that the frequency of consumption of a certain tree species (Vatairea macrocarpa) was considerably higher than the frequencies of consumption of nine other species in a cerradão remnant in southwestern Cerrado (RagusaNetto, 2006). Similarly, in my study, the frequency of consumption of $A$. humile seeds was substantially higher than that of six other plant species. It was common to find several flock members feeding simultaneously on these seeds at firebreaks. As the consumption of a given plant species was recorded only once for a given feeding flock, the importance of $A$. humile seeds might have been underestimated in my study.

\section{Seasonality}

No flocks of feeding macaws were recorded in the studied firebreaks between November and February. Restriction of foraging activities to September and October might have occurred for an important reasonthe availability of $A$. humile seeds. Patches of $A$. humile harbored abundant fruits between early September and mid October; fruits were rare and dehydrated from late October. As their seeds were the major food items of the macaws, it is likely that reduction in their availability made firebreaks less attractive as foraging sites. This might have led macaws to feed in other areas of the landscape from mid October.

\section{Vertical strata as foraging places}

Although large macaws feed mainly on trees (Forshaw, 1989; del Hoyo et al., 1997; Juniper and Parr, 1998), flocks of the Blue-and-yellow Macaw often forage on the ground at firebreaks. This fact was evidenced by: 1) the use of a short plant (A. humile patches) as the major food source, 2) the higher frequency of consumption of shrubs in comparison to that of trees, and 3) the finding of $A$. humile patches surrounded by trampled grass. It was noted that consecutive visits of macaw flocks to a given patch modified the surrounding grass layer, as most macaws fed on A. humile seeds while on the ground.

Similar findings of large macaws feeding on the ground had been reported elsewhere. For example, Anodorhynchus hyacinthinus flocks were noted feeding on Acrocomia aculeata nuts at cattle rumination sites in the Pantanal (Yamashita, 1997). My study is the first to report the landing of Blue-and-yellow Macaw feeding flocks in the Cerrado, as previous studies reported them foraging on trees (Villalobos, 1994; Sick, 1997; Bianchi, 1998; Ragusa-Netto, 2006; Faria et al., 2007).

At Emas National Park, the ground of woodland and grassland firebreaks appears to be a suitable foraging site for the Blue-and-yellow Macaw in September and October. Three aspects of vegetation might contribute to attracting macaws to these areas managed for fire control. First, firebreaks provide a food resource $(A$. humile seeds) in abundance. Second, as park managers burn firebreaks by June, the tall and dominant capim flecha is much shorter during this period of the year, and in the following year. Thus, macaws can land and take off from the ground without hitting their feathers against this dense grass. Third, the densities of trees and shrubs appear to be low enough to permit landing and taking off without obstructing flight movements, and high enough to provide perches near major feeding sites (A. humile patches). This is because flocks do not land immediately after arriving at firebreaks. They perch on trees, shrubs or termite nests prior to their foraging activities on the ground. These perches above the grass layer also provide sentinel perches against predators for flock members at firebreaks. 
Although firebreaks might provide abundant food (especially A. humile seeds), landing on the ground might have negative aspects. This macaw species is occasionally preyed upon by maned wolves (Chrysocyon brachyurus) in Cerrado areas (Bianchi et al., 2000; Juarez and Marinho Filho, 2002). This canid species was seen on a nearly daily basis at one study site, and every two or three days at the other site, thus representing a potential predation threat to macaw flocks. Such predation risk appears not to inhibit macaw flocks in obtaining the highly nutritious Anacardium seeds (Almeida et al., 1998) and other food resources after their nesting period.

\section{Interactions between macaws and the flora at firebreaks}

Macaws are considered as major seed predators (del Hoyo et al., 1997; Juniper and Parr, 1998). At the studied firebreaks, flocks were noted preying seeds of three shrub species (Anacardium, Allagoptera and Campomanesia). Most records of exploitation of these plant species at firebreaks involve fruit damage and seed consumption. Therefore, the Blue-and-yellow Macaw should be considered as a seed predator of these species. Its role as predator might be most intense for Anacardium humile, as macaws usually leave dozens of broken fruits on the ground after completing their foraging activities on a given fruiting patch. More detailed studies could try to quantify rates of damage to fruits or seeds, as has been done for psittacid species in other regions (e.g. Francisco et al., 2002; Trivedi et al., 2004).

Although the Blue-and-yellow Macaw often preyed upon seeds at the studied firebreaks, it occasionally dispersed seeds as well. On a few occasions, macaws were noted leaving the ground with a branch bearing fruit (Anacardium and Campomanesia) or with the whole fruit stalk (Allagoptera). After perching or during the flight, the macaw let these parts harboring damaged and undamaged fruits fall down at firebreaks or on adjacent grassland and woodland, probably in response to my presence. Thus, it is likely that similar dispersal events (Synzoochory; van der Pijl (1982)) might take place in response the approach of predators or some other reason.
The diet of the Blue-and-yellow Macaw can also include non-reproductive parts of plants (del Hoyo et al., 1997; Juniper and Parr, 1998). At firebreaks, this involved tree species. Although damage to growing parts of Pouteria was apparently reduced, small flocks were seen causing substantial damage to Erythroxylum and Pseudobombax. Similar records of extensive damage to young non-reproductive parts of trees have not been made previously for the Blue-and-yellow Macaw (del Hoyo et al., 1997; Juniper and Parr, 1998).

\section{Conservation issues}

Native physiognomies such as veredas, grasslands, woodlands and forests provide food and nesting resources for the Blue-and-yellow Macaw (Villalobos, 1994; Bianchi, 1998; Ragusa-Netto, 2006) and should be considered as its major habitats in the Cerrado. On the other hand, firebreaks could be considered as recent landscape elements that might influence their survival and other demographic parameters. This is because the use of firebreaks by their flocks appeared to be opportunistic, as their foraging activities were related to the fruiting season of an abundant plant (A. humile). Thus, my results highlight the notion that distant portions of the landscape might be important in some periods of the year for species that breed, roost and forage mainly in narrow patches of vegetation (veredas, in this case). Therefore, appropriate conservation plans for the Blueand-yellow Macaw should include protection not only of veredas but also parts of the landscape which are often and seasonally used as foraging sites. Research on their annual dietary choices is necessary to better understand the use of landscapes by the Blue-and-yellow Macaw.

As firebreaks are human-modified bands of vegetation, planning of their location, extension and burning period within the Cerrado's reserves should consider their use by native species, such as the Blueand-yellow Macaw. As firebreaks are adjacent to roads, protection by park managers could increase in months marked by frequent visits by macaws, in order to reduce potential threats due to poaching and car traffic at, or adjacent to, the firebreaks. Alternatively, the use by macaws of unsafe firebreaks (e.g., along park limits) could be reduced through the burning of firebreaks 
a few weeks before the $A$. humile fruiting season, to reduce seed availability. Further research is necessary to better understand the use by native fauna of firebreaks and to guide management activities targeting wildlife conservation within nature reserves in the Cerrado.

\section{Acknowledgements}

I thank IBAMA for providing a license to conduct research at Emas National Park. Rogério O. Souza helped with logistic support. Mário B. Ramos provided a vegetation map of Emas NP. Margarete N. Sato kindly identified the plant species. Aline Fujikawa, José Carlos Motta Junior, Dr. Paulo Hofmann and two anonymous reviewers improved this manuscript with constructive suggestions. This study received financial support from the Fundação de Amparo à Pesquisa do Estado de São Paulo/FAPESP (proc. 05/00773-3) and the Conselho Nacional de Desenvolvimento Científico e Tecnológico/ CNPq (proc. 471360/2006-6).

\section{References}

Almeida, S. P.; Proença, C. E. B.; Sano, S. M.; Ribeiro, J. F. 1998. Cerrado: Espécies vegetais úteis. Embrapa, Planaltina, Brasil, 464pp.

Assad, E. D. 1994. Chuva nos cerrados. Análise e espacialização. Embrapa/SPI, Brasília, Brazil, 423pp.

Ayres, M.; Ayres Jr, M.; Ayres, D. L.; Santos, S. A. 2000. BioEstat 2.0. $3^{\text {rd }}$ ed. Sociedade Civil Mamirauá, Belém, Brasil, 272pp.

Bianchi, C. A. 1998. Biologia reprodutiva de arara-canindé (Ara ararauna, Psittacidae) no Parque Nacional das Emas, Goiás. Dissertação de Mestrado, Universidade de Brasília, Brasil, 69pp.

Bianchi, C. A.; Bagno, M. A.; Juarez, K. M. 2000. Predation of Ara ararauna and Amazona aestiva (Psittaciformes, Psittacidae) by Chrysocyon brachyurus (Carnivora, Canidae) in the Cerrado, Brazil. Ararajuba, 8 (1): 49-50.

Brightsmith, D.; Bravo, A. 2006. Ecology and management of nesting blue-and-yellow macaws (Ara ararauna) in Mauritia palm swamps. Biodiversity and Conservation, 15 (13): 4271-4287.

Castro, E. A.; Kauffman, J. B. 1998. Ecosystem structure in the Brazilian Cerrado: A vegetation gradient of aboveground biomass, root mass and consumption by fire. Journal of Tropical Ecology, 14 (3): 263-283.

Coutinho, L. M. 1978. O conceito de Cerrado. Revista Brasileira de Botânica, 1 (1): 17-23.

del Hoyo, J.; Elliott, A.; Sargatal, J. 1997. Handbook of the birds of the world, v. 4, Sandgrouse to Cuckoos. Lynx Edicions, Barcelona, Spain, 679pp.
Eiten, G. 1972. The cerrado vegetation of Brazil. Botanical Review, 38 (2): 205-341.

Faria, I. P.; Abreu, T. L. S.; Bianchi, C. A. 2007. Seed and fruit predation of Kielmeyera (Guttiferae) and Qualea (Vochysiaceae) species by six Psittacid species in the Brazilian Cerrado. Ecotropica, 13 (1): 75-79.

Forshaw, J. 1989. Parrots of the world. $3^{\text {rd }}$ ed. Landsowne Editions, Willoughby, Australia, 616pp.

França, H.; Ramos Neto, M. B.; Setzer, A. 2007. O fogo no Parque Nacional das Emas. Ministério do Meio Ambiente, Brasília, Brasil, $101 \mathrm{pp}$.

Francisco, M. R.; Lunardi, V. O.; Galetti, M. 2002. Massive seed predation of Pseudobombax grandiflorum (Bombacaceae) by parakeets Brotogeris versicolurus (Psittacidae) in a forest fragment in Brazil. Biotropica, 34 (4): 613-615.

Gilardi, J. D.; Munn, C. A. 1998. Patterns of activity, flocking, and habitat use in parrots of the Peruvian Amazon. Condor, 100 (4): 641-653.

Haugaasen, T.; Peres, C. A. 2005. Tree phenology in adjacent Amazonian flooded and unflooded forests. Biotropica, 37 (4): 620630.

Haverschmidt, F. 1954. Evening flights of the Southern Everglade Kite and the Blue and Yellow Macaw in Surinam. Wilson Bulletin, 66 (4): 264-265.

Juarez, K. M.; Marinho Filho, J. 2002. Diet, habitat use, and home ranges of sympatric canids in central Brazil. Journal of Mammalogy, 83 (4): 925-933.

Juniper, T.; Parr, M. 1998. A guide to the parrots of the world. Pica Press, Sussex, UK, 594pp.

Oehler, D. A.; Boodoo, D.; Plair, B.; Kuchinski, K.; Campbell, M.; Lutchmedial, G.; Ramsubage, S.; Maruska, E. J.; Malowski, S. 2001. Translocation of blue and gold macaw Ara ararauna into its historical range on Trinidad. Bird Conservation International, 11 (2): 129-141.

Oliveira Filho, A. T.; Ratter, J. A. 2002. Vegetation physiognomies and woody flora of the Cerrado biome. In: Oliveira, P. S. \& Marquis, R. J. (Eds). The Cerrados of Brazil. Ecology and natural history of a neotropical savanna. Columbia University Press, New York, USA, p.91-120.

Oliveira, P. S.; Marquis, R. J. 2002. The Cerrados of Brazil. Ecology and natural history of a neotropical savanna. Columbia University Press, New York, USA, 398pp.

Ragusa-Netto, J. 2006. Dry fruits and the abundance of the Blueand-Yellow Macaw (Ara ararauna) at a cerrado remnant in central Brazil. Ornitologia Neotropical, 17 (3): 491-500.

Ramos Neto, M. B.; Pivello, V. R. 2000. Lightning fires in a Brazilian savanna national park: Rethinking management strategies. Environmental Management, 26 (6): 675-684.

Renton, K. 2002. Seasonal variation in occurrence of macaws along a rainforest river. Journal of Field Ornithology, 73 (1): 15-19.

Ribeiro, J. F.; Walter, B. M. T. 1998. Fitofisionomias do Bioma Cerrado. In: Sano, S. M. \& Almeida, S. P. (Eds). Cerrado. Ambiente e flora. Embrapa, Planaltina, Brasil, p.89-166.

Roth, P. 1984. Repartição do habitat entre psitacídeos simpátricos no Sul da Amazônia. Acta Amazônica, 14 (1-2): 175-221. 
Scariot, A.; Sousa-Silva, J. C.; Felfili, J. M. 2005. Cerrado: Ecologia, biodiversidade e conservação. Ministério do Meio Ambiente, Brasília, Brasil, 439pp.

Sick, H. 1997. Ornitologia brasileira. Editora Nova Fronteira, Rio de Janeiro, Brasil, 862pp.

Sigrist, T. 2006. Aves do Brasil. Uma visão artística. Fosfertil, São Paulo, Brasil, 672pp.

Stotz, D. F.; Fitzpatrick, J. W.; Parker, T. A.; Moskovits, D. K. 1996. Neotropical birds. Ecology and conservation. University of Chicago Press, Chicago, USA, 478pp.
Trivedi, M.R.; Cornejo, F. H.; Watkinson, A. R. 2004. Seed predation on Brazil nuts (Bertholletia excelsa) by macaws (Psittacidae) in Madre de Dios, Peru. Biotropica, 36 (1): 118-122.

van der Pijl, L. 1982. Principles of dispersion in higher plants. Springer-Verlag, Berlin, Germany, 214pp.

Villalobos, M. P. 1994. Guilda de frugívoros associada com o buriti (Mauritia flexuosa: Palmae) numa vereda no Brasil central. Dissertação de Mestrado, Universidade de Brasília, Brasil, 78pp.

Yamashita, C. 1997. Anodorhynchus macaws as followers of extinct megafauna: An hypothesis. Ararajuba, 5 (2): 176-182. 